\title{
Removal Site Evaluation Report for the SRL Seepage Basins
}

by

E. R. Palmer

Westinghouse Savannah River Company

Savannah River Site

Aiken, South Carolina 29808

This paper was prepared in connection with work done under the above contract number with the U. S.

Department of Energy. By acceptance of this paper, the publisher and/or recipient acknowledges the U. S. Government's right to retain a nonexclusive, royalty-free license in and to any copyright covering this paper, along with the right to reproduce and to authorize others to reproduce all or part of the copyrighted paper. 


\section{DISCLAMMER}

Portions of this docoment may be Illegible in electronic image prodnets. Irogges are produced from the best available original docoment 


\section{DISCLAIMER}

This report was prepared as an account of work sponsored by an agency of the United States Government. Neither the United States Government nor any agency thereof, nor any of their employees, makes any warranty, express or implied, or assumes any legal liability or responsibility for the accuracy, completeness, or usefulness of any information, apparatus, product, or process disclosed, or represents that its use would not infringe privately owned rights. Reference herein to any specific commercial product, process, or service by trade name, trademark, manufacturer, or otherwise does not necessarily constitute or imply its endorsement, recommendation, or favoring by the United States Government or any agency thereof. The views and opinions of authors expressed herein do not necessarily state or reflect those of the United States Government or any agency thereof.

This report has been reproduced directly from the best available copy.

Available to DOE and DOE contractors from the Office of Scientific and Technical Information, P.O. Box 62, Oak Ridge, TN 37831; prices available from (615) 576-8401.

Available to the public from the National Technical Information Service, U.S. Department of Commerce; 5285 Port Royal Road, Springfield, VA 22161. 
WSRC-RP-97-164

\section{REMOVAL SITE EVALUATION REPORT}

FOR THE

SRL SEEPAGE BASINS (U)

AUGUST 1997

REVISION 1

WESTINGHOUSE SAVANNAH RIVER COMPANY

SAVANNAH RIVER SITE

AIKEN, SC 29802

\section{DISCLAIMER}

This report was prepared by Westinghouse Savannah River Company (WSRC) for the United States Department of Energy under Contract No. DE-AC09-96-SR18500 and is an account of work performed under that contract. Reference herein to any specific commercial product, process, or service by trademark, name, manufacturer or otherwise does not necessarily constitute or imply endorsement, recommendation, or favoring of same by WSRC or by the United States Government or any agency thereof. 


\subsection{INTRODUCTION}

Removal Site Evaluation Reports are prepared in accordance with Section 300.410 and 300.415 of the National Contingency Plan (NCP) and Section X of the Federal Facility Agreement (FFA). The Savannah River Laboratory (SRL) Seepage Basins is one of the units that is listed in the Appendix C, Resource Conservation and Recovery Act (RCRA)/Comprehensive Environmental Response, Compensation, and Liability Act (CERCLA) Units List, of the FFA. The purpose of this investigation is to report information concerning conditions at this unit sufficient to assess the threat (if any) posed to human health and the environment and to determine the need for additional CERCLA action. The scope of the investigation included recent surveys and sampling data, reviews of historical data, and visits to the unit.

Through this investigation, unacceptable conditions of radioactive contaminant uptake in on-site vegetation were identified. This has resulted in introduction of contamination into the local ecological food chain and probable contaminant migration through biotic pathways. As a result, the Savannah River Site (SRS) will initiate a time critical removal action to remove and dispose of contaminated vegetation from the SRL Seepage Basins. Potential erosion in affected areas will be inhibited by implementation of the SCDHEC approved Stormwater Management and Sediment Reduction Plan/Pollution Prevention Plan, Permit \# SCR-100221. This report addresses the removal of the vegetation within the SRL Seepage Basin fence and, if necessary, the vegetation immediately outside the fence. The remediation of the waste unit will be addressed in other CERCLA documentation.

\subsection{UNIT DESCRIPTION, OPERATIONAL HISTORY, AND WASTE CHARACTERISTICS}

\section{$2.1 \quad$ Location}

A map showing the SRL Seepage Basins in relation to the locations of the major SRS facilities is included in figure A-1 of Appendix A. The basins are located in the northwestern section of SRS, about $4000 \mathrm{ft}$ from the nearest SRS boundary and $4500 \mathrm{ft}$ from the nearest residence. A more detailed map of the immediate vicinity is shown in figure A-2 of Appendix A. This map shows that the basins lie within the northern portions of the A/M Area, north of the Savannah River Ecology Laboratory (SREL) and northeast 
of the Savannah River Technology Center (SRTC). See Photograph B-1 of Appendix B for an-aerial photograph of the SRL Seepage Basins. Road 1-A is located immediately west of the basins, and Tims Branch is located immediately to the north. The setting to the north, east, and south of the basins is wooded. An unnamed intermittent stream is also located immediately east of the basins. The area to the west is cleared and vegetated with low grasses. All compass directions in this section refer to the site coordinate system which is oriented $36^{\circ} 22^{\prime}$ west of true north. (RFI/RI Work Plan for the SRL Seepage Basins (U), WSRC-RP-95-156, Rev. 1, July 1996)

\subsection{Site Description}

The SRL Seepage Basins consist of four unlined basins that received low-level radioactive wastewater from the Savannah River Laboratory until 1982. Basins 1 and 2 were placed into operation in 1954, and Basins 3 and 4 were added in 1958 and 1960, respectively. Basins 1, 2, and 3 were constructed by excavating below the original ground surface. The basin floors and the berm walls below the original ground surface are undisturbed native soils. Because the original topography north of Basin 3 sloped toward Tims Branch, the materials removed during Basin 4 construction were used as fill to construct part of its basin floor, portions of its western and eastern perimeter, and all of the northern perimeter berm. Waste was transferred from the laboratories to the basins via a $900 \mathrm{ft}$ long, $10 \mathrm{in}$. diameter, clay process sewer line pipe that discharged into the western end of Basin 1 . The four basins are connected by a series of sequential overflow channels. The SRL Seepage Basins total approximately 2.15 acres and have the following dimensions:

\begin{tabular}{|c|c|c|c|}
\hline Basin No. & Length feet & Width feet & Depth feet \\
\hline 1 & 129 & 62 & 11 \\
\hline 2 & 129 & 129 & 11 \\
\hline 3 & 176 & 125 & 11 \\
\hline 4 & 300 & 150 & 14 \\
\hline
\end{tabular}

The basins are currently surrounded by an 8 - $\mathrm{ft}$ high chain-linked fence with a small animal barrier along the base. The animal barrier does not penetrate the ground surface. Inside the fence, the basins and the adjacent interior portions of the berms are delineated as a radiological controlled area. A buffer area exists between the delineated area and the basin fence. Grass in the buffer area is mowed periodically. Various grasses, bushes, and weeds have established themselves in the basins, and trees are presently growing on the intra- 
basin berms, within the actual basins, and on the northern perimeter berm of Basin 4. See Photograph B-2 of Appendix B for typical vegetation growth within the basins. Access roads to the groundwater wells that surround the basins are located just outside the fence and run to the south of Basin 1 and east of Basins 1, 2, and 3. Following heavy precipitation, standing water would be expected in all four basins, and in dryer times of the year all of the basins may be dry.

The northern edge of the basins is bounded by Tims Branch, which is approximately 50 feet away. The topography falls steeply at a 20 percent grade from the northern edge of Basin 4. An unnamed tributary to Tims Branch is approximately 154 feet from the southern edge of Basin 1. The topography falls at a 10.5 percent grade to the tributary branch. (RFI/RI Work Plan)

The eastern edge of the basin is also bounded by the same unnamed tributary. Basins 1,2, and 3 are approximately 220 feet away while the eastern edge of Basin 4 is 112 feet away. Topography from the eastern edges of Basins 1,2 and 3 falls steeply at a 23 percent grade to the stream bed. Topography from the eastern edge of Basin 4 falls at a 11 percent grade to the unnamed tributary bed.

\subsection{Operational History and Waste Characteristics}

Basins 1 and 2 (Building Numbers 904-53G and 904-53G1) were placed into operation in 1954, and Basins 3 (Building No. 904-54G) and 4 (Building No. 904-55G) were added in 1958 and 1960, respectively. The basins were used from 1954 to 1982 to dispose of lowlevel radioactive liquid waste generated in the laboratories located in Buildings 735-A and 773-A. The laboratory-derived low-level liquid waste was stored in Building 776-A waste tanks until the activity was confirmed to be below $100 \mathrm{dpm} / \mathrm{ml}$ alpha and/or $50 \mathrm{dpm} / \mathrm{ml}$ beta-gamma. Waste meeting this transfer criterion was then sent to Basin 1 via the process sewer line. Waste that did not meet this criterion was transferred to the H-Area Tank Farm by tanker truck. The average activity for waste discharged to the basins was 50 $\mathrm{dpm} / \mathrm{ml}$ for both alpha and beta-gamma. During the 28 years of operation, the basins received $4,549,000 \mathrm{ft}^{3}$ of wastewater or about $162,000 \mathrm{ft}^{3} / \mathrm{yr}$. The following table lists the discharges of low-level waste-water to the SRL Seepage Basins. 


\begin{tabular}{|l|r|c|}
\hline Period & Volume $\left(\mathbf{f t}^{\mathbf{3}}\right)$ & Volume/Yr $\left(\mathbf{f t}^{\mathbf{3}}\right)$ \\
\hline \hline $1954-1971$ & $3,250,000$ & 191,000 \\
1972 & 237,000 & 237,000 \\
$1973-1977$ & 561,000 & 112,400 \\
$1978-1982$ & 501,000 & 100,000 \\
\hline \hline Total (1954-1982) & $4,549,000$ & 162,000 \\
\hline
\end{tabular}

The transfer records from 1958-1980 were reviewed and a summary of these historical discharges of radionuclides to the SRL Seepage Basins is presented in the following table:

\begin{tabular}{||l|c|}
\hline Parameter & Activity (Ci) \\
\hline H-3 & 105 \\
\hline Sr-89,90 & 0.4 \\
\hline Cs-137 & 4.7 \\
\hline Natural U & 0.022 \\
\hline Pu-238 & 0.009 \\
\hline Pu-239 & -0.003 \\
\hline Am 241 & 0.001 \\
\hline Cm-242, 244 & 0.001 \\
\hline Ru-103, 106 & 1.4 \\
\hline Co-60 & 0.1 \\
\hline Ce-141, 144 & 2.7 \\
\hline Alpha (unidentified) & 4.2 \\
\hline Beta-gamma (unidentified) & 10.6 \\
\hline
\end{tabular}

Over the extended period, Tritium (H-3) was the primary radionuclide discharged to the basins. At the end of basin operation in 1982, the radioactive content of the waste transferred to the basins averaged $0.0004 \mathrm{Ci}$ per month and contained uranium-238 (90\%), plutonium-238 (5\%), and plutonium-239 (5\%). This change in the waste's nuclide distribution resulted from laboratory mission changes.

Based on the historical data, the following are the primary chemical constituents discharged to the basin over its 28 year life: nitrate $\left(\mathrm{NO}_{3}\right)$, sulfate $\left(\mathrm{SO}_{4}\right)$ sodium $(\mathrm{Na})$, 
chlorine $(\mathrm{Cl})$, calcium $(\mathrm{Ca})$, phosphorus $(\mathrm{P})$, chromium $(\mathrm{Cr})$, and silicon $(\mathrm{Si})$. Process knowledge suggests that no significant quantities of chlorinated organics were discarded to the low-level tanks of Building 776-A or the SRL Seepage Basins.

In late 1971, two non-routine releases were made to the SRL Seepage Basins during decontamination of the SRL high-level caves. In the first release, contaminated wash water leaked into the SRL Auxiliary Pipe Trench beneath E-wing, Building 773-A, and then seeped into a storm sewer that discharges to Tims Branch. When the leak was discovered, the Tims Branch was dammed below Road 1A, and the contaminated water was pumped to SRL Seepage Basin 4. In the second release, highly contaminated water entered the 904-A Process Trench and was inadvertently transferred to the low-level waste system instead of the high-level waste system. It was subsequently discharged to SRL Seepage Basin 1. The primary isotope identified for both transfers was Curium-244 (Cm-244). Cobalt-60 (Co-60) and Cerium-144 (Ce-144) were also detected. It was estimated that about $0.315 \mathrm{Ci}$ and $0.680 \mathrm{Ci}$ of $\mathrm{Cm}-244$ were released to Tims Branch/Basin 4 and Basin 1, respectively. (RFI/RI Work Plan)

\subsection{SAMPLING DATA/MONITORING HISTORY}

\subsection{Sampling Data}

Investigations involving sediment/soil and vegetative sampling have been performed within the limits of the basins. Additionally, certain portions of the interior of the process sewer line and soils around the sewer line have been sampled. Sampling is being performed on the vegetation immediately outside the basin fence to determine the extent of the contamination. The following sections provide sampling data history for each of these areas.

\subsubsection{Soil Sampling}

Soil sampling was implemented in 1983. The latest soil sampling program began during 1996 and was completed in May 1997. The results of the 1996 - 1997 soil sampling will be addressed in detail in a future CERCLA document. Cores were taken to a depth of 20 $\mathrm{ft}$ in the basins. The samples were analyzed for radionuclides, metals, cations, anions, and organic compounds. 
Preliminary review of the analytical results from the soil samples indicate the contaminants are cancentrated in the first 1 to $2 \mathrm{ft}$ beneath the basin bottom. Below the first few feet of basin sediments, the contaminant concentrations generally drop to the detection limit. In general, the contaminants were found to decrease in concentration from Basin 1 to Basin 4. The most abundant metals detected in the sediments were manganese (Mn), magnesium $(\mathrm{Mg})$, zinc $(\mathrm{Zn})$, chromium $(\mathrm{Cr})$, sodium $(\mathrm{Na})$, copper $(\mathrm{Cu})$, nickel $(\mathrm{Ni})$, and lead $(\mathrm{Pb})$, in decreasing order. Sulfate $\left(\mathrm{SO}_{4}\right)$ was the most concentrated inorganic ion detected in basin sediments. The radionuclides detected in the basins are consistent with the contents of the low-level radioactive waste water that was discharged to the basins, as identified in the previous table. (RFI/RI Work Plan)

\subsubsection{Vegetation Sampling}

In 1991 and again in 1997, samples of vegetation were collected within the perimeter of the four seepage basins to determine uptake of radionuclides by vegetation. Figure $\mathrm{C}-1$ in Appendix C shows locations of the samples collected in 1997. Samples from the basins were run for a suite of radiochemical parameters. A comparison of the gross Alpha, nonvolatile Beta, and Cesium-137 (Cs-137) was conducted to test if the trees should be considered as radioactive. The data were compared to the only existing background data at SRS - a set of 26 background samples collected around the H-Area. The background data and summary arithmetic statistics for the gross Alpha, non-volatile Beta, and Cs-137 are presented in Table 1. A threshold of mean plus two standard deviations was selected to separate background from contaminated samples. In addition, the three results were added, named Sum Rad, to calculate the relative intensity of radioactivity.

For this evaluation and statistical treatment, both detects and non-detects were used. Also, the data were not manipulated based on below detection limit criteria. Two of the $28 \mathrm{H}$ Area background samples contained highly anomalous sample results and were removed from the background data for this evaluation.

The radiochemical data and "Sum Rad" (a summary of the gross Alpha, non-volatile Beta and Cs-137 activities) for the SRL Seepage Basins are shown in figure C-I of Appendix C. The actual sampling data for the SRS Seepage Basins is shown in Table 2.

All samples in the SRL Seepage Basins exceed the background mean plus two standard deviations for gross Alpha, non-volatile Beta, Cs-137 and Sum Rad. The mean Sum Rad 
variable for the SRL Seepage Basins is nearly 100 times greater than for the background data, $513 \mathrm{pCi} / \mathrm{g}$ to $5 \mathrm{pCi} / \mathrm{g}$. Note: $1 \mathrm{pCi} / \mathrm{g}$ equals $10^{-12} \mathrm{Ci} / \mathrm{g}$. (Craig, Robert R., April 24, 1997, Comparison of Tree Radiochemical Samples from the SRL Seepage Basin Data to H-Area Background Data, ESH-EMS-970440, Savannah River Site, Aiken, South Carolina)

Sampling and analysis of vegetation outside the SRL Seepage Basin fence is being performed to identify current activity levels within the vegetation. The purpose of the sampling is to:

- Identify which vegetation outside the fence has been affected by contaminant uptake from contamination inside the seepage basin.

- Identify contaminated vegetation outside the fence to be cleared. 
Table 1. Data and summary arithmetic statistics from selected H-Area background data. All results are in $\mathrm{pCi} / \mathrm{g}$. Coordinates are in SRS grid.

\begin{tabular}{|c|c|c|c|c|c|c|}
\hline SID & Easting & Northing & G Alpha & NV Beta & Cs-137 & Sum Rad \\
\hline $106600(\mathrm{LD})$ & 60406 & 71333 & 3.06 & 8.08 & 0.88 & 12.02 \\
\hline $106600(\mathrm{LD})$ & 60406 & 71333 & 2.48 & 7.47 & 0.52 & 10.47 \\
\hline 106602 & 60084 & 70653 & 1.03 & 3.12 & 0.29 & 4.44 \\
\hline 106603 & 59952 & 70809 & 1.20 & 4.35 & 0.79 & 6.34 \\
\hline 106604 & 59727 & 70832 & 1.72 & 3.26 & 0.03 & 5.01 \\
\hline 106605 & 59487 & 70966 & 1.92 & 4.28 & 1.10 & 7.30 \\
\hline $106606(\mathrm{FD})$ & 59918 & 70009 & 1.82 & 5.08 & 0.59 & 7.49 \\
\hline 106607(FD) & 59918 & 70009 & 1.23 & 4.96 & 0.49 & 6.68 \\
\hline 106608 & 59563 & 70288 & 0.69 & 2.16 & 0.06 & 2.91 \\
\hline 106609 & 59225 & 70772 & 3.48 & 4.04 & 0.23 & 7.75 \\
\hline 106610 & 59217 & 72023 & 1.60 & 4.61 & 0.23 & 6.44 \\
\hline 106611 & 59302 & 72601 & 1.39 & 3.78 & 0.47 & 5.64 \\
\hline 106612 & 59302 & 72601 & 2.74 & 4.27 & 0.64 & 7.65 \\
\hline $106613(\mathrm{LD})$ & 59015 & 72615 & 0.33 & 2.21 & 0.25 & 2.79 \\
\hline $106613(\mathrm{LD})$ & 59015 & 72615 & 0.18 & 2.02 & 0.05 & 2.25 \\
\hline 106614 & 59795 & 72447 & 0.03 & 2.03 & 0.19 & 2.25 \\
\hline 106615 & 59638 & 72411 & -0.39 & 2.81 & 0.90 & 3.32 \\
\hline 106616 & 59452 & 72310 & -0.56 & 1.53 & 0.99 & 1.96 \\
\hline 106617 & 59345 & 72395 & 0.03 & 5.27 & 0.39 & 5.69 \\
\hline 106618 & 60525 & 71272 & 0.03 & 3.01 & 0.33 & 3.37 \\
\hline 106619 & 60702 & 71265 & -1.66 & 3.83 & 0.46 & 2.63 \\
\hline 106620 & 61122 & 70945 & -1.16 & 2.87 & 1.03 & 2.74 \\
\hline 106621 & 61033 & 70807 & 0.03 & 2.34 & 0.70 & 3.07 \\
\hline 106623 & 61366 & 70808 & -0.74 & 4.04 & 0.91 & 4.21 \\
\hline 106624 & 60246 & 70525 & -0.66 & 1.66 & 0.07 & 1.07 \\
\hline 106625 & 60110 & 70130 & 1.21 & 4.43 & 0.43 & 6.07 \\
\hline $\mathrm{n}$ & & & 26 & 26 & 26 & 26 \\
\hline $\min$. & & & -1.66 & 1.53 & 0.03 & 1.07 \\
\hline $\max$. & & & 3.48 & 8.08 & 1.10 & 12.02 \\
\hline mean & & & 0.81 & 3.75 & 0.50 & 5.06 \\
\hline std. & & & 1.330 & 1.617 & 0.329 & 2.712 \\
\hline skew & & & 0.190 & 1.010 & 0.292 & 0.790 \\
\hline mean $+2 \sigma$ & & & 3.469 & 6.985 & 1.159 & 10.483 \\
\hline
\end{tabular}

LD $=$ Laboratory Duplicate $\quad F D=$ Field Duplicate 
Table 2. Data and summary arithmetic statistics from SRL Seepage Basin. All results are in $\mathrm{pCi} / \mathrm{g}$. Coordinates are in SRS grid.

\begin{tabular}{|r|r|r|r|r|r|r|}
\hline SID & Easting & Northing & ALPHAG & BETAG & CS137 & Sum Rad \\
\hline 107301 & 52888 & 105862 & 1.31 & 56.71 & 2.71 & 60.73 \\
\hline 107302 & 52972 & 105934 & 6.28 & 81.28 & 5.19 & 92.75 \\
\hline 107303 & 52982 & 105902 & 2.34 & 61.84 & 37.48 & 101.66 \\
\hline 107304 & 52982 & 105902 & 0.98 & 71.38 & 39.22 & 111.58 \\
\hline 107305 & 53115 & 105782 & 0.9 & 21.15 & 3.1 & 25.15 \\
\hline 107307 & 53105 & 105706 & 55.36 & 3181.58 & 12.55 & 3249.49 \\
\hline 107309 & 53060 & 105653 & 15.34 & 619.27 & 0.65 & 635.26 \\
\hline 107310 & 53024 & 105732 & 2.47 & 61.17 & 7.97 & 71.61 \\
\hline 107312 & 52946 & 105790 & 1.57 & 80.63 & 18.16 & 100.36 \\
\hline 107315 & 52984 & 105836 & 0.21 & 36.38 & 59.52 & 96.11 \\
\hline 107317 & 52932 & 105732 & 1.13 & 73.61 & 293 & 367.74 \\
\hline 107318 & 52942 & 105706 & 21.92 & 81.55 & 199.7 & 303.17 \\
\hline 107319 & 52918 & 105756 & 1.96 & 67.26 & 106.1 & 175.32 \\
\hline 107322 & 52842 & 105825 & 2.63 & 44.96 & 140.8 & 188.39 \\
\hline 107324 & 52778 & 105770 & 2.89 & 35.7 & 323.6 & 362.19 \\
\hline 107325 & 52788 & 105754 & 4.09 & 82.44 & 244.1 & 330.63 \\
\hline 107331 & 52730 & 105716 & 0.57 & 138.48 & 32.12 & 171.17 \\
\hline 107333 & 52694 & 105685 & 0.41 & 103.25 & 25.9 & 129.56 \\
\hline 107337 & 52738 & 105574 & 0.15 & 187.68 & 49.73 & 237.56 \\
\hline 107339 & 52802 & 105632 & 0.99 & 33.81 & 26.78 & 61.58 \\
\hline 107340 & 52810 & 105646 & 3.01 & 461.77 & 56.28 & 521.06 \\
\hline 107341 & 52802 & 105658 & 2.57 & 447.54 & 112.2 & 562.31 \\
\hline 107344 & 52632 & 105628 & 1.08 & 286.88 & 25.66 & 313.62 \\
\hline 107346 & 52610 & 105612 & 4.15 & 632.97 & 8.11 & 645.23 \\
\hline 107350 & 52676 & 105525 & 27.12 & 3231.14 & 529.1 & 3787.36 \\
\hline 107353 & 52712 & 105562 & 4.78 & 410.71 & 5.67 & 421.16 \\
\hline 107355 & 52676 & 105608 & 4.85 & 722.01 & 5.08 & 731.94 \\
\hline $\mathrm{n}$ & & & & & & 27 \\
\hline mean & & & 27 & 27 & 27 & 27 \\
\hline std & & & 11.781 & 830.108 & 127.318 & 892.561 \\
\hline mean+20 & & & 29.897 & 2079.221 & 342.431 & 2298.259 \\
\hline
\end{tabular}




\subsection{Groundwater Monitoring History}

Twenty-one monitoring wells are presently installed around the basins. Locations of these existing monitoring wells are shown in Figure C-2 of Appendix C.

To evaluate the effect that basin contamination may have on groundwater, a groundwater quality assessment was conducted on data collected from 6 of the monitoring wells. The monitoring wells were sampled quarterly and analyzed for metals, inorganics, organics and radioactive indicator parameters. Additional sampling and analysis is being performed as part of the RFI/RI characterization to include specific analysis of radionuclides. When the recently collected data becomes available, the full extent of the potential impact to the groundwater will be addressed in detail in future documents as part of the CERCLA process.

Wastewaters discharged to the basins were solutions of inorganic salts and radionuclides which contained primarily sodium $(\mathrm{Na})$, aluminum $(\mathrm{Al})$, calcium $(\mathrm{Ca})$, iron $(\mathrm{Fe})$, zinc $(\mathrm{Zn})$, manganese $(\mathrm{Mn})$, chloride $(\mathrm{Cl})$, sulfate $\left(\mathrm{SO}_{4}\right)$ and nitrate $\left(\mathrm{NO}_{3}\right)$ ions.

Groundwater monitoring data from the third and fourth quarters of 1994 and the first quarter of 1995 indicate that Tritium contamination is consistently above PDWS in upper Lost Lake aquifer zone wells ASB-2CR and ASB-10CR. Several wells in the vicinity of the basins exhibit elevated levels of several organic compounds that may be associated with the known A/M Area groundwater contaminant plume that originates upgradient of the SRL Seepage Basins. Any additional impacts to groundwater that may have resulted from the discharge of low-level radioactive wastewater to the SRL Seepage Basins will be addressed in detail in future CERCLA documents. (RFI/RI Work Plan)

\subsection{GROUNDWATER PATHWAY}

\subsection{Hydrologic Setting}

Groundwater and surface water characteristics are largely controlled by physiography and subsurface stratigraphy. SRS is located on the Upper Coastal Plain, approximately 20 miles southeast of the Fall Line, which separates the Piedmont and Coastal Plain provinces. SRS is on the Aiken Plateau, a relatively flat area that slopes southeastward and is dissected by several tributaries of the Savannah River. The major tributaries that occur on SRS are Upper Three Runs Creek, Fourmile Branch, Tinker Creek, Pen Branch, 
Indian Grave, Steel Creek, and Lower Three Runs Creek. SRS is underlain by a 700 to $1,20 \mathrm{f} \mathrm{ft}$ thick, seaward-thickening wedge of Coastal Plain sediment composed of unconsolidated sands, clayey sands, sandy clays, and lesser amounts of calcareous sediment. These layers are underlain by dense crystalline igneous and metamorphic rock or younger consolidated sediments of the Triassic Period. Within the Coastal Plain sediments, the sandy strata are generally porous and permeable and may form aquifers.

In the A/M Area, the Southeastern Coastal Plain hydrogeologic province consists of the Floridan-Midville Aquifer System, which includes the McQueen Branch Aquifer, the Crouch Branch Aquifer, and the Steed Pond Aquifer.

The majority of the monitoring wells within the A/M Area including the SRL Seepage Basins are constructed in water-bearing sediments comprising the Steed Pond Aquifer.

The Crouch Branch Confining Unit separates the underlying Crouch Branch Aquifer from the overlying Steed Pond Aquifer and is recognized regulatorily as the principle confining unit for the A/M Area.

Within the $\mathrm{A} / \mathrm{M}$ Area, approximately $30 \%$ of precipitation, or $15 \mathrm{in} . / \mathrm{yr}$, enters the groundwater system. Precipitation in the A/M Area predominantly infiltrates and recharges the Steed Pond Aquifer. The Crouch Branch Aquifer receives recharge from an outcrop area approximately 2.5 miles north of the $\mathrm{A} / \mathrm{M}$ Area and from the overlying Steed Pond Aquifer through the Crouch Branch Confining Unit. Discharge from the Crouch Branch Aquifer occurs to the southwest along the Savannah River. (RFI/RI Work Plan) -

\subsection{Groundwater Targets}

There are three primary domestic water production wells, 905-118G, 905-112G and 905113G, within one mile of the SRL Seepage Basins. Production well 905-118G is located approximately .5 miles to the northeast of the Basins; wells $905-112 \mathrm{G}$ and $905-113 \mathrm{G}$ are located approximately one mile to the east of the SRL Seepage Basins. These wells are screened in the Crouch Branch and McQueen Branch aquifers. The screened zones vary in depth from 365 feet to 683 feet below the ground surface. Groundwater flow in these aquifers is to the south-southwest. With respect to proximity to the SRL Seepage Basins, well $905-118 \mathrm{G}$ is located upgradient and wells $905-112 \mathrm{G}$ and $905-113 \mathrm{G}$ are located side- 
gradient to groundwater flow. As a result, these wells are not positioned in the direction of groundwater flow from the SRL Seepage Basins.

There are also 5 process wells (905-81A, 99A, 98A, 82A, and 31A) located approximately one mile south-east of the SRL Seepage Basins that provide process water to various facilities within the $\mathrm{A} / \mathrm{M}$ Area. These wells are screened in the deeper Crouch Branch and McQueen Branch aquifers, and are located in the downgradient direction of groundwater flow.

The primary cause of groundwater contamination in the $\mathrm{A} / \mathrm{M}$ Area is from process activities in $M$ Area. Six recovery wells are currently remediating groundwater in the area of the process water wells. These recovery wells are screened in the shallow Lost Lake aquifer. The objective of the recovery wells is to remediate groundwater and control vertical and lateral plume migration.

\subsection{Groundwater}

Groundwater remediation in the $\mathrm{A}$ and $\mathrm{M}$ Areas is already in progress under the RCRA Permit Number SC1-890-008-989 to address several organic compounds associated with a known $\mathrm{A}$ and $\mathrm{M}$ Area groundwater contaminant plume that originates upgradient of the SRL Seepage Basins. Any additional impact to groundwater that may have resulted from discharges to the SRL Seepage Basins will be addressed in detail in future documents as part of the CERCLA process.

\subsection{SURFACE WATER PATHWAY}

\subsection{Hydrologic Setting}

Surface water in the vicinity of the SRL Basins consists of two natural intermittent streams: Tims Branch and an unnamed tributary to Tims Branch. In the vicinity of the seepage basins, these two streams are approximately 100 feet above the water table in the unsaturated zone. Water in the unsaturated zone will infiltrate downward in the absence of a continuous confining layer and enter the groundwater. No such confining layer has been identified in the area of the SRL Seepage Basins in the unsaturated zone.

The confluence of the two tributaries is approximately 200 feet east of Basin 4 . At this point the combined tributaries flow east, then southeasterly, to a point about four miles 
southeast where it joins the Upper Three Runs Creek. Two tributaries are fed by stormwater runoff from SRL complex and the surrounding terrain. They are also recipients of SRTC and Savannah River Ecology Laboratory (SREL), NPDES-permitted wastewater discharges. Additional waters from SREL greenhouses, duck ponds and alligator ponds enter the tributary from the southwest.

\subsection{Surface Water Targets}

Entrance and exposure to surface water contained within the basins is prohibited by a 8 foot high chain link fence. In addition, this fence has a solid plate at the base around the entire perimeter to prevent small animals from entering the basin area. All moisture that falls within the confines of the controlled basin area remains within the basin proper and does not exit the site. There is no evidence of seepage from the basins through the exterior berms around the basin; therefore no subsurface flow is exiting and being received by the Tims Branch and the unnamed tributary. Ecological exposures to direct contact with water in the basins is limited to species that can get through, under or around the fencing (such as birds and insects), and to plant and animal species that permanently reside in the basins.

\subsection{Surface Water Conclusions}

Under the current conditions, little potential impact from the SRL Seepage Basins to surface water exists through surface water runoff. From the previous discussions, ecological exposures occur only from direct contact with the water in the basins. Contaminants in the standing water may be assimilated by plants growing in the basin and by animal species that reside permanently in the basin or that can penetrate the basin perimeter. The plants are accessible to foraging wildlife. The removal of the vegetation that has assimilated contamination will reduce the ecological exposure route and supports the time critical removal action.

\subsection{SOIL EXPOSURE AND AIR PATHWAYS}

\subsection{Physical Conditions}

Soil types in the vicinity of the SRL Seepage Basins are described in the following paragraphs:

The seepage basins are within the Udorthent friable substratum (Uo) land complex. These soils are composed of spoil from previously excavated and disturbed areas and borrow 
pits. Because of the disturbed nature of the soils, soil properties may vary within a few feet. T-ypically, the surface layer and substratum to a depth of $6 \mathrm{ft}$ consist of red, brown, and yellow loamy and sandy material. The Uo soil series tends to have a very low organic content, is strongly acidic, and has a low available water capacity. Permeability is generally moderate but may range from moderately low to high.

Vaucluse-Ailey Complex ( $\mathrm{VeC}$ ) soils occur adjacent to the SRL Seepage Basins along Tims Branch and the unnamed tributary of Tims Branch. The Vaucluse soil and the Ailey soil are so intermingled that they can not be mapped separately.

Typically, the Vaucluse soil has a surface layer of brown sandy loam about 5 in. thick. The subsoil from a depth of 5 to $10 \mathrm{in}$. is strong brown sandy clay loam; from 10 to $17 \mathrm{in}$. is yellowish red sandy clay loam; from 17 to $20 \mathrm{in}$. is strong brown sandy clay; from 20 to 32 in. is red sandy loam; and from 32 to 62 in. is reddish brown sandy clay loam. The substratum from 62 to 72 in. is reddish yellow sandy loam. The Vaucluse soil typically has a low organic matter content and a low available water capacity. It is strongly acidic to extremely acidic throughout. Permeability is low or moderately low.

Typically, the Ailey soil has a surface layer of brown sand about 6 in. thick. The subsurface layer from a depth of 6 to 26 in. is brown sandy clay loam; and from 40 to 55 in. it is sandy clay loam that is coarsely mottled in shades of brown and red. The substratum from 55 to 65 in. is coarsely mottled red, brown, and gray sandy loam. The Ailey soil has a low organic matter content and a low available water capacity. It is strongly acidic or very strongly acidic throughout. Permeability is low in the subsōil.

The Fuquay Sand $(\mathrm{FuB})$ is typically a grayish brown sand from the surface to a depth of approximately 8 in. Underlying this from a depth of 8 to 22 in. is yellowish brown sand. Deeper subsoils are mottled, yellowish brown, red, light gray and strong brown sandy clay loams. The FuB soils are well drained, with a low organic content, and moderately to strongly acidic. Permeability is low through the lower portions of the subsoils.

Dothan sand (DoB) is well drained and has moderate permeability. The upper 7 in. is a brown sand. Beneath this layer are 7 to 12 in. of yellowish brown sandy loam with red and brown mottles. Deeper subsoils are strong brown to yellowish brown, sandy clay loam with red, brown, and gray mottles. The DoB soil has a low organic content and moderate 
available water capacity. It is moderately to very strong acidic, becoming increasingly acidic in the lower subsoils. (RFI/RI Work Plan)

Contamination discharged to the basins is expected to reside in the surface soils.

\subsection{Soil and Air Targets}

The basins are surrounded by a chain-link fence which has a solid metal barrier at its base. Thus, direct contact with basin soils requires access to the basins. For human exposures, this would correspond to the on-site worker. Ecological exposures to direct contact with basins soils is limited to species that can get through, under or around the fencing (such as birds and insects), and to plant and animal species that permanently reside in the basins. There is potential for uptake from the contaminated soil by vegetation at the SRL Seepage Basins. These plants are accessible to foraging wildlife that can penetrate the basin perimeter. Plants can absorb contaminants from the soil. Animals can ingest contaminated plant material, and can contact soil directly.

Volatilization of contaminants from basin water and wind suspension of contaminated soils may result in airborne contamination, resulting in on-unit exposures. Wind dispersion will dilute airborne contamination and spread it to surrounding areas, resulting in exposures to off-unit workers and off-site residents. Wind can also disperse plant debris. Important aspects of the biotic pathway are discussed in greater detail below.

Biotic Transport - Contaminants in the basin soils may be assimilated by plants growing within the basins. Invertebrate and vertebrate species in the basins may access contamination through the ingestion of contaminated plant matter. Other species which in turn feed on these species may accumulate even greater contaminant loadings. Elevated concentrations of metals and radionuclides have been detected in trees growing within the basins, and elevated concentrations of Sr-90 and Cs-137 have been found in turtles removed from the basins, supporting a time critical removal action of the basin vegetation. While contamination of birds and flying insects is unlikely to pose a human health risk, as the only major biotic path out of the basin unit, it could contribute to ecological risk.

\subsection{Soil Exposure and Air Pathway Conclusions}

As a result of surface contamination and vegetation uptake, the SRL Seepage Basins pose a risk of radionuclide exposure to on-site workers and the local animal populations. Contamination is currently being introduced into the local ecological food chain through 
vegetation uptake. Ecological targets are more susceptible due to the higher frequency and longer-duration of exposure to contaminated soils and vegetation within the basin.

SRS has determined that action to address uncontrolled uptake and release of contaminates by local vegetation is warranted. This action, to be outlined below, will remove the quantity and variety of vegetation including berry producing plants and pollen producing trees. The action will minimize the possibility of soil erosion from the basins to unrestricted areas.

The need for final remediation at the basins will be addressed in future CERCLA documents. The proposed actions initiated to address contaminated vegetation at the SRL Seepage Basins will not interfere with RI/FS process and will be selected to be consistent with potential final remedies.

\subsection{SUMMARY AND CONCLUSIONS}

The Savannah River Laboratory (SRL) Seepage Basins are located in the northwestern section of the Savannah River Site (SRS), about 4000 feet from the nearest SRS boundary. The unit consists of four unlined basins that received low-level radioactive wastewater from the former SRL until 1982. Waste was transferred from the laboratories to Basin 1 via a $900 \mathrm{ft}$ long, 10 in. diameter, clay process sewer line pipe. The four basins are connected by a series of sequential overflow channels. Tritium (H-3), strontium-90 (Sr-90), and cesium-137 (Cs-137) were the major radionuclides discharged to the basins. Sodium $(\mathrm{Na})$, aluminum $(\mathrm{Al})$, calcium $(\mathrm{Ca})$, iron $(\mathrm{Fe})$, zinc $(\mathrm{Zn})$, manganése $(\mathrm{Mn})$, chloride $(\mathrm{Cl})$, sulfate $\left(\mathrm{SO}_{4}\right)$ and nitrate $\left(\mathrm{NO}_{3}\right)$ ions were the primary chemical constituents discharged to the basins. The contamination in the basins is approximately 100 feet above the water table.

The basins are surrounded by an $8 \mathrm{ft}$ high chain-linked fence with a small animal barrier along the base. Inside this fence, the basins and the adjacent interior portions of the berms are delineated as a radiological controlled area. A buffer area exists between the delineated area and the basin fence.

In addition to soil contamination, uptake of radioactive contaminants has caused the vegetation in the SRL Seepage Basins and possibly the vegetation in the surrounding area 
to become contaminated. Contaminated vegetation has increased the radiation doses at the unit as well as introduced radioactive contaminants into the ecological food chain. As a result of this vegetation growth, the SRS intends to perform a time critical removal action to remove contaminated vegetation and institute controls to avoid future growth. This removal action will involve contaminated vegetation and will minimize disturbance of basin soils and sediments. All vegetation (trees, shrubs and vines) will be removed from within the basins. Vegetation will be cut and sectioned. Final disposition of this material will be in accordance with the approval of WSRC-RP-97-427. The proposed removal action outlined in this document is to dispose of the vegetation at the SRS Low Level Disposal Facility. After removal of contaminated vegetation, the SRL Seepage Basins will be routinely monitored for changing conditions. New vegetation growth will be limited to short grasses through seeding and inspection to remove saplings.

\subsection{TECHNICAL SPECIFICATIONS}

All vegetation will eventually be removed from within the basins. Removal of the larger trees will also include removal of roots to approximately 9 inches below grade. All vegetation will be disposed of as noted in Section 7.0. Vegetation removal will be performed to minimize land disturbance and therefore the potential for soil erosion. Land disturbances will be addressed in an approved soil erosion control plan which will minimize the potential for release of contaminated soil to the surrounding areas and exposure to on-site workers. In order to minimize erosion, some contaminated soil may be moved to a stable location either inside the SRL Seepage Basins fence or to an approved off-unit location. Some vegetation may be removed from the area outside the SRL Seepage Basin fence based on the results of the sampling program presently in progress.

Vegetation requiring removal from the waste unit will be cut, sectioned, and packaged for transport at the waste unit. Appropriate process designs and procedures will be used to ensure radiation exposure during all operations is As Low As Reasonably Achievable (ALARA). If necessary, wind breaks and rad huts will be employed to reduce the risk from wind blown contamination. In addition, SRS procedures do not allow activity in contamination areas when wind velocity reaches 10 miles per hour at the work location. Wind breaks may be used when velocities exceed 10 miles per hour. Handling of trees and larger vegetation may be performed remotely which may include the use of cranes or other mechanized equipment used in the logging industry. 
It is anticipated that the contaminated vegetation will be taken to the SRS Low Level Disposal Facility for final disposal. After removal of contaminated vegetation, a follow-up report, will be submitted documenting the volume and disposition of all vegetation removed from the unit.

After removal of contaminated vegetation, the SRL Seepage Basins will be routinely monitored for changing conditions. New vegetation growth will be limited to short grasses through seeding and inspections to remove saplings. 


\section{REFERENCES}

Craig, Robert R., April 24, 1997, Comparison of Tree Radiochemical Samples from the SRL Seepage Basin Data to H-Area Background Data, ESH-EMS-970440, Savannah River Site, Aiken, South Carolina.

RFI/RI Work Plan for the SRL Seepage Basins (U), WSRC-RP-95-1556, Rev. 1, July 1996 Sections 2.0 and 3.5, Savannah River Site, Aiken, South Carolina. 
WSRC-RP-97-164

Sheet 1 of 3

APPENDIX A MAPS 
WSRC-RP-97-164

Appendix A Sheet 2 of 3

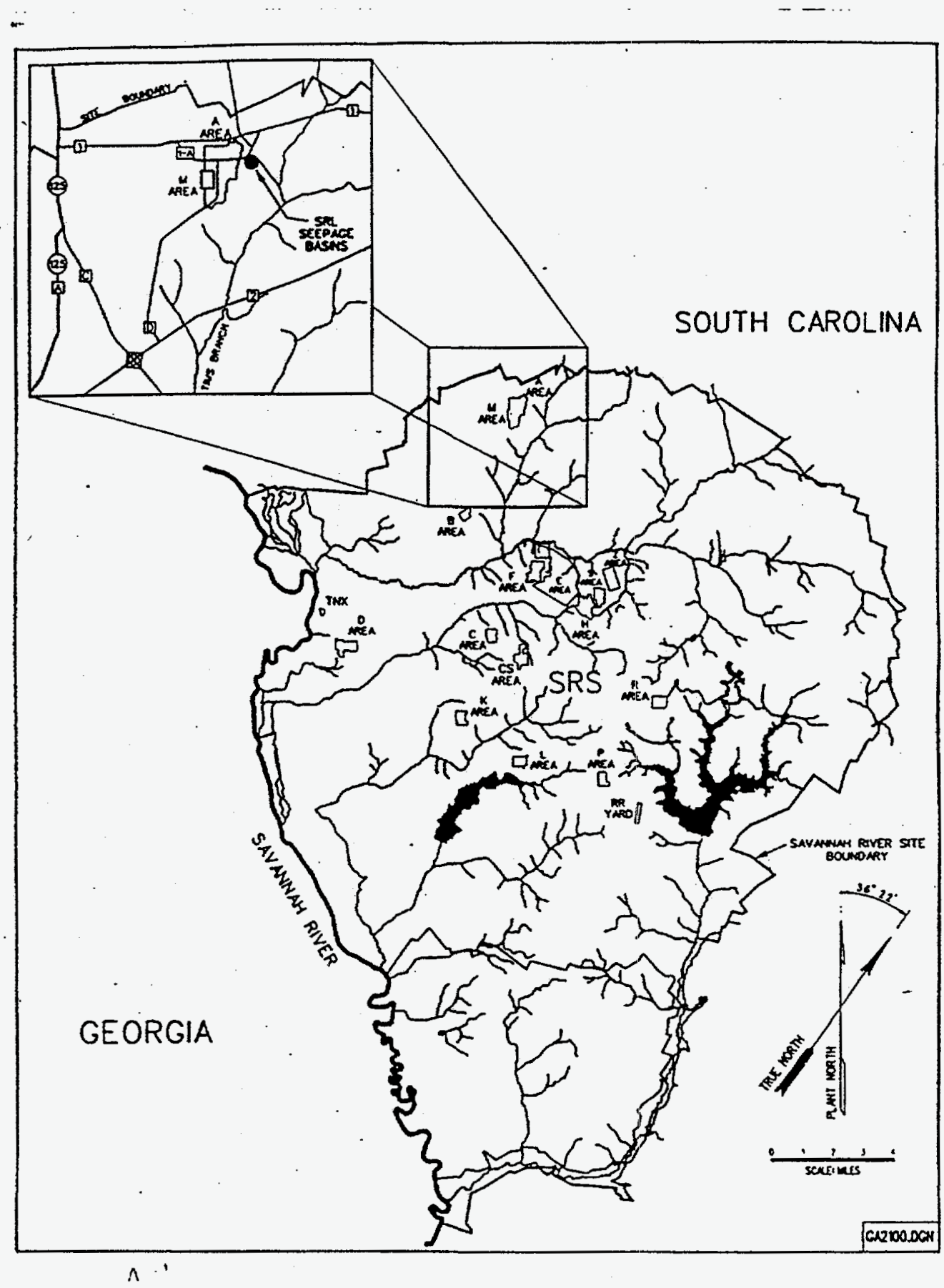

FIGURE A-1 Location of the SRL Seepage Basins with respect to the Savannah River Site 


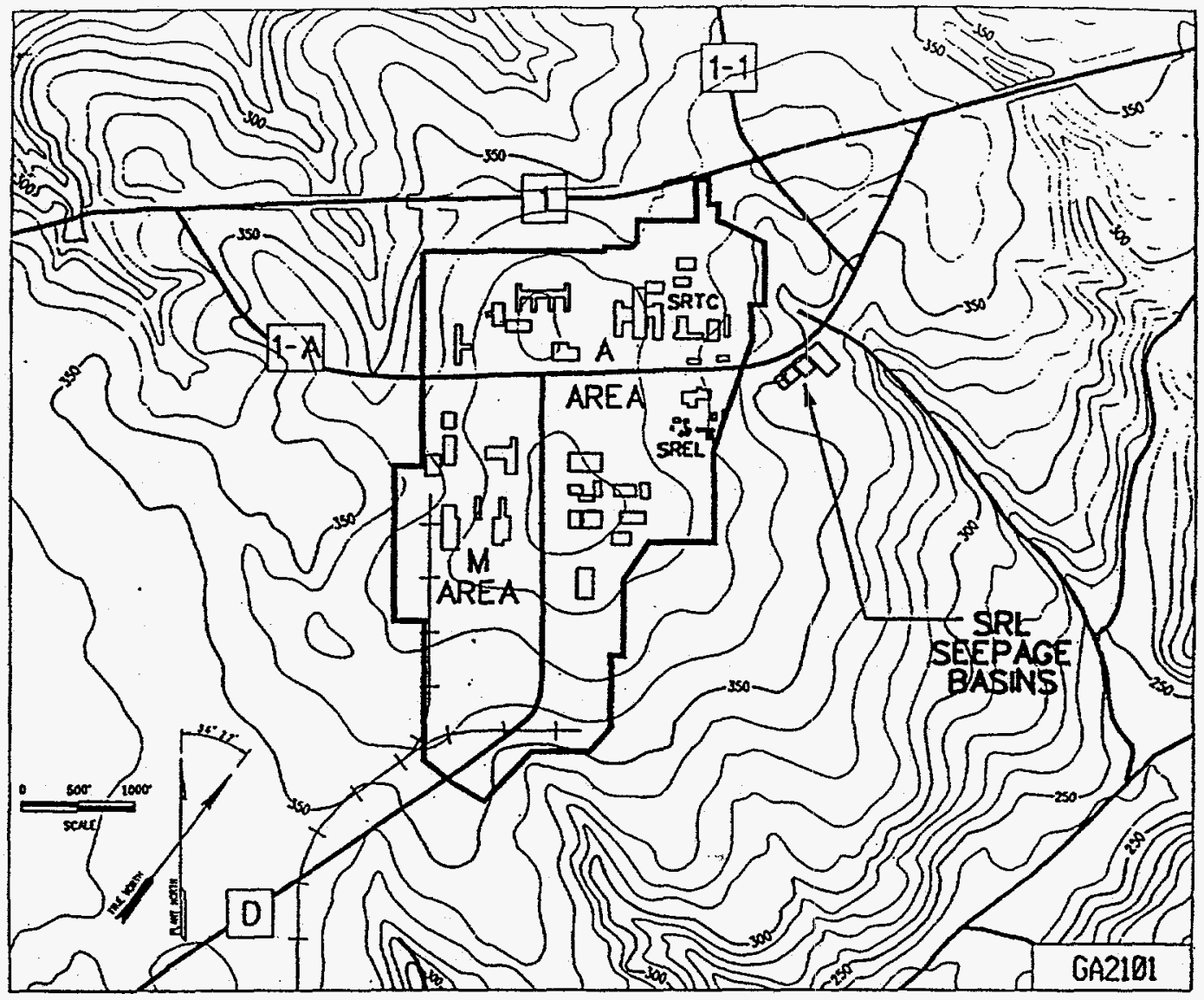

FIGURE A-2 Location of SRL Seepage Basins in the A/M Area 
WSRC-RP-97-164

Sheet 1 of 3

APPENDIX B

PHOTOGRAPHS 
WSRC-RP-97-164

Appendix B Sheet 2 of 3

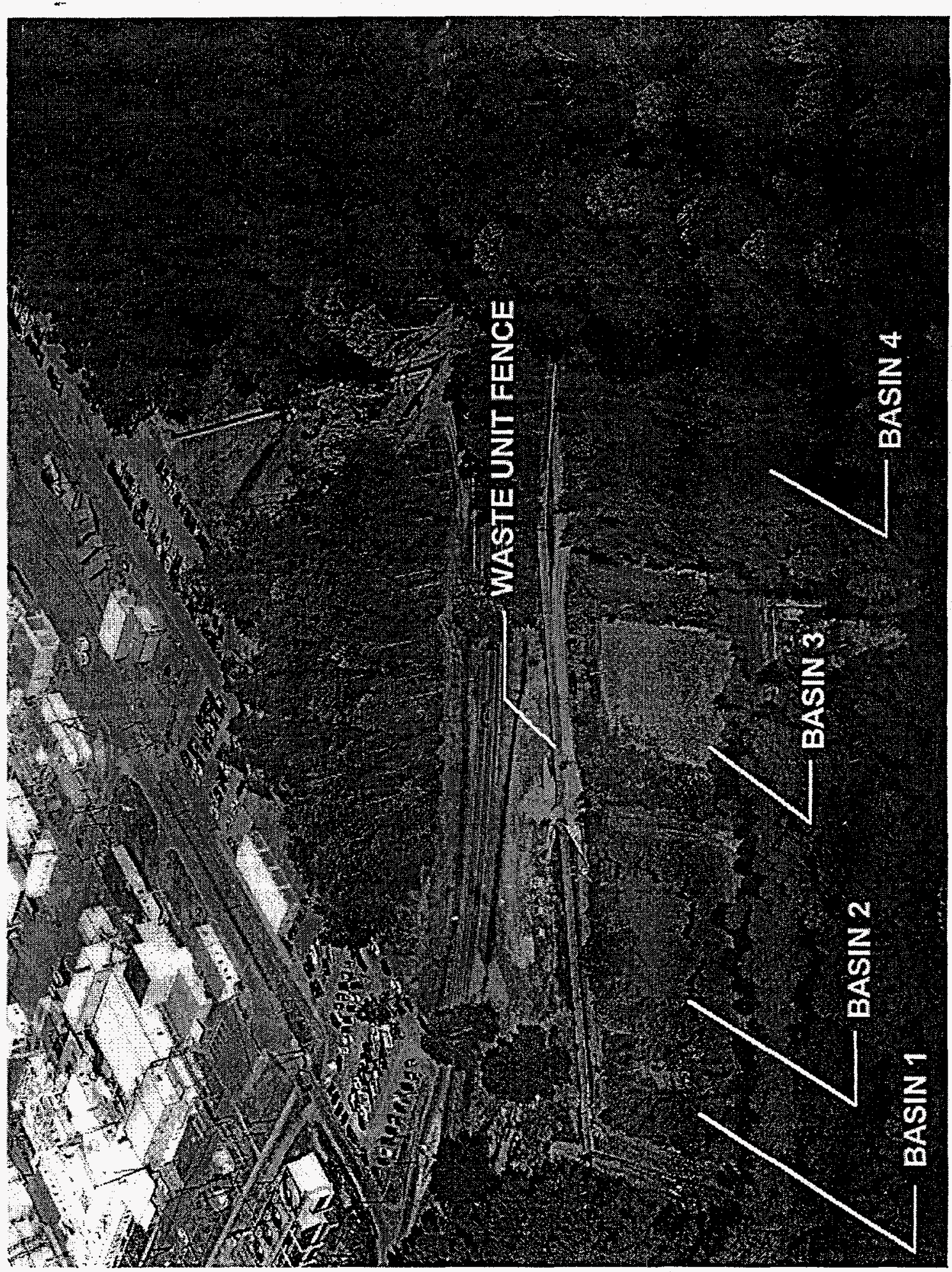

Photograph B-I Aerial Photograph of the SRL Seepage Basins 
WSRC-RP-97-164

Appendix B Sheet 3 of 3

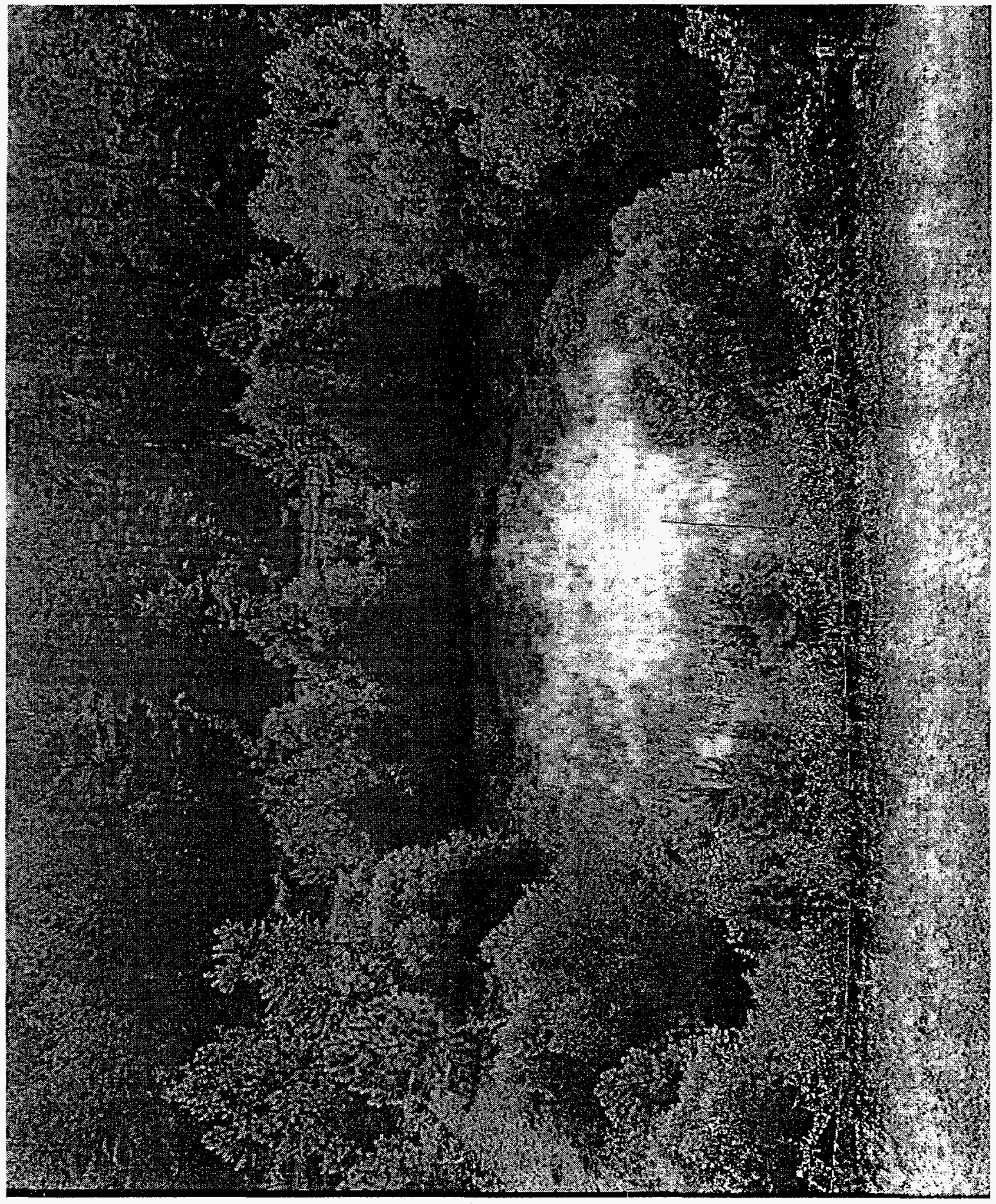

Photograph B-2 Example of vegetation growth in SRL Seepage Basin 2 


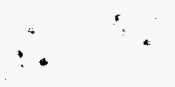

$+$

WSRC-RP-97-164

Sheet 1 of 3

APPENDIX C

SAMPLING INFORMATION 


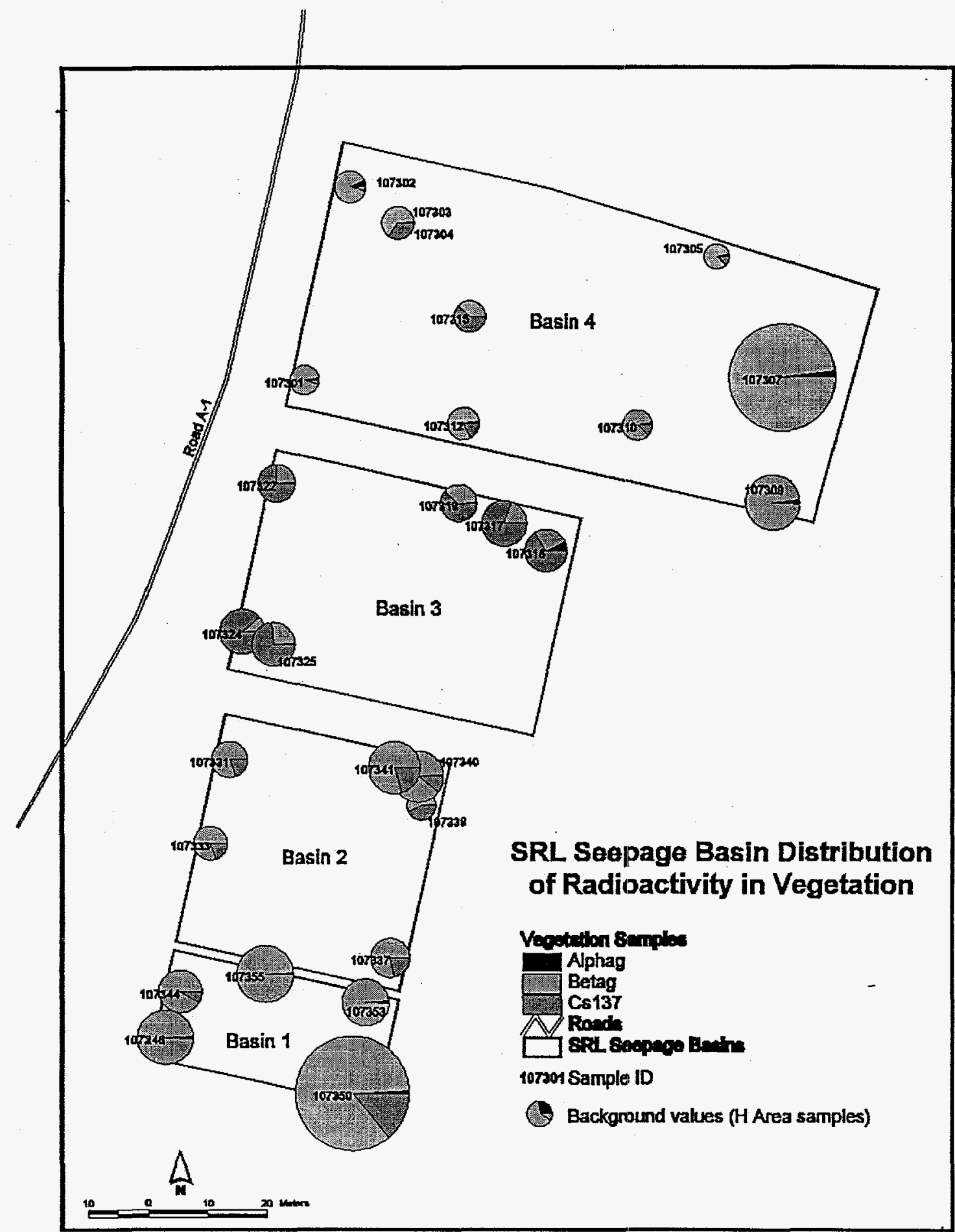

FIGURE C-I Vegetation sampling locations within the SRL Seepage Basin 
WSRC-RP-97-164

Appendix C Sheet 3 of 3

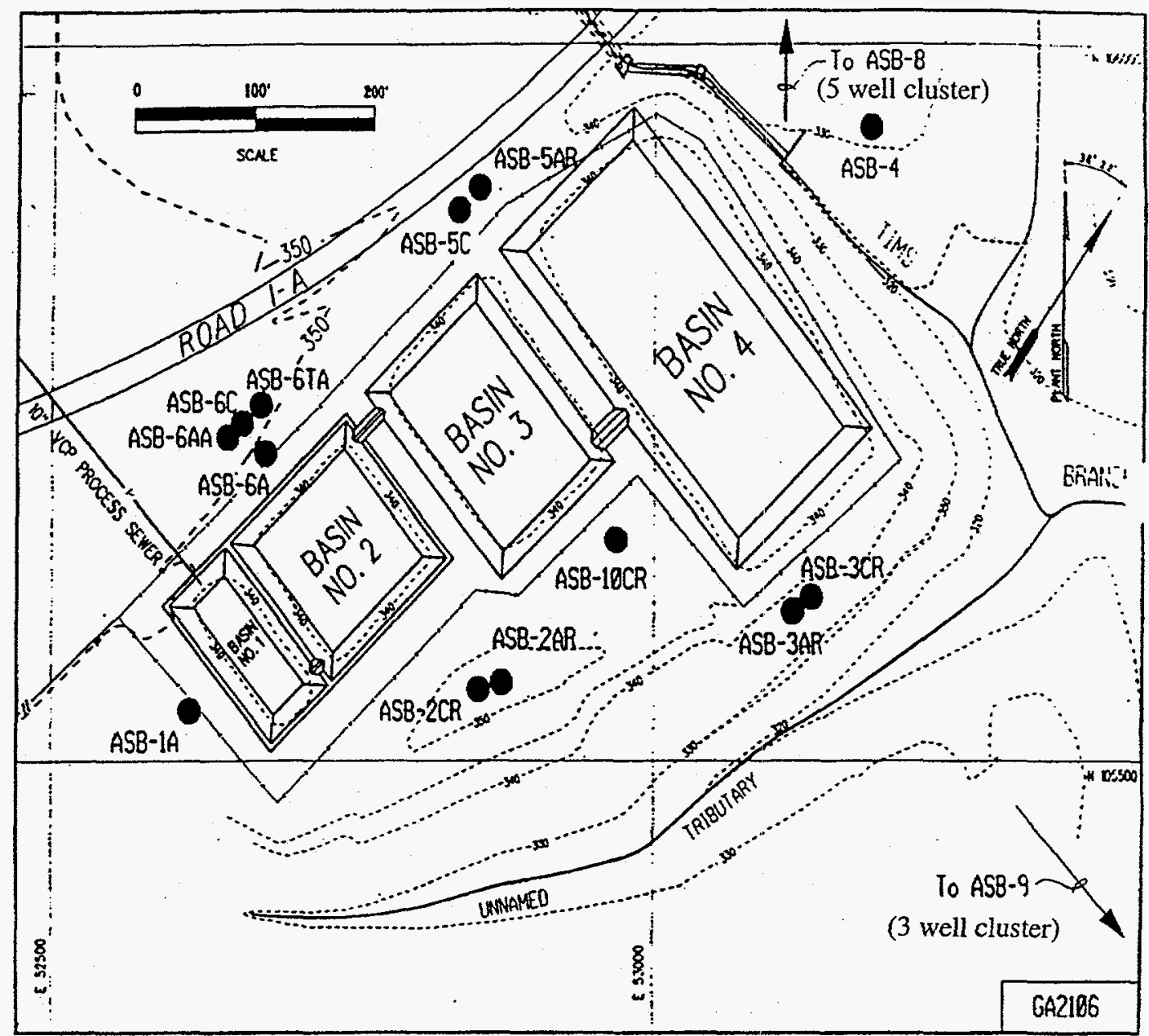

FIGURE C-2 Groundwater monitoring well locations at the SRL Seepage Basins 